systems, the installation of emergency lighting, the improvement of work space, and remodeling aimed to facilitate team work and efficient use of space.

Renovations began during the Annual Meeting, while the majority of the staff was in San Francisco, and continued through mid-September. The Membership Services, Personnel Service and Annual Meeting offices experienced minor delays in processing requests due to this undertaking.

\section{Membership Insurance Benefits Go On-Line}

The Customer Service Department of Albert H. Wohlers \& Co., our Group Insurance Administrator, is now on the Internet.

The Wohlers Company has established two new E-Mail addresses to assist members with their insurance needs. The new E-Mail addresses are: cusv@ahw.com and info@ahw.com.

Members can use cusv@ahw.com to reach Wohlers' Customer Service Department with any questions regarding the insurance plans. Members seeking information-such as brochures or applications for the plans-should use info@ahw.com to receive these materials in the mail.

When using the Internet to contact the Wohlers Company, it is important for members to include the following information: name, complete address, date of birth, spouse date of birth, telephone number and name of association. This will enable them to provide members with complete and accurate details on the insurance plans.

\section{Library of Congress Institutes New Reader Registration System}

In an effort to enhance security of collections and make a more effective and serviceable system for users, the Library of Congress is implementing photographic Reader Registration Cards. The new badges will be required to use Library collections and 19 reading rooms. Patrons wishing to use the public reading rooms and the Library's collections should report to a badging station located on the ground floor of the Jefferson Building.

At badging station computers, patrons will key in their names, addresses, telephone numbers, and the first five digits of their social security numbers, their primary topic of research, the purpose of use, and the primary format of the materials used. All this information-including a photo and signature - will be included in a database, which can be accessed by authorized staff throughout the Library. Reading room staff will scan a patron's barcode, which will activate the patron's online record. That record will show whether the card is valid for use in a specific reading room. If the card is valid, the materials ordering process will continue. If the card is not valid, the patron will have to undergo further proceedings in order to obtain materials.

The badge issued to registered readers will be valid for a period of two years or less and must be renewed at the end of the period for which it is issued.

\section{NSF Appoints New Director for Law and Social Science Program}

Dr. Harmon Hosch was appointed Program Director of the National Science Foundation's Law and Social Science Program, effective September 3, 1996. Dr. Hosch was a professor of law and psychology at the University of Texas, El Paso. He succeeds Dr. Neal Tate who has returned to the political science department at the University of North Texas in Denton, Texas.

\section{German Marshall Fund of the United States Appoints Program Director for Central and Eastern Europe}

The German Marshall Fund of the United States has announced the appointment of Krystyna Wolniakowski as Program Director for the Fund's grantmaking activities and projects in Central and Eastern Europe.

As Program Director for Central and Eastern Europe, Ms. Wolniakowski will manage the Fund's grantmaking program, developing initiatives that will include projects and fellowship exchanges supporting political development and environmental reform. She will also administer a major project funded by the United States Agency for International Development (USAID) and the German Marshall Fund to develop greater citizen participation in local governance and policymaking. Ms. Wolniakowski will work out of the Fund's office in Berlin.

\section{Section News}

\section{APSA Organized Sections Distribute Awards at Annual Meeting}

Nineteen APSA Organized Sections presented awards at the 1996 Annual Meeting to recognize distinctive scholarship and career service within their fields of political science. Winners are listed below.

\section{Federalism and Intergovernmental Relations}

The Distinguished Scholar Award recognizing distinguished scholarly contributions to the study of federalism and intergovernmental relations was presented to Richard P. Nathan, SUNY-Albany. The Best Paper Award, conferred for the best paper in the field of federalism and intergovernmental relations presented at the previous years APSA Annual Meeting was awarded to Daniel Treisman, Harvard University, Richard Cole, University of Texas, Arlington, Carl W. Stenberg, University of Baltimore, and Carol W. Weissert, Michigan State University, for their paper "A Ranking of Key Intergovernmental Relations, Events, Issues and Trends: 1980-1995." The Best Book Award was presented to Morton J. Grodzins, University of Chicago, for The American System. This award is conferred for the best book on federalism and intergovernmental relations published at least ten years ago that has made a lasting contribution to the study of federalism and intergovernmental relations. 